Original Article

\title{
EVALUATION OF ETHOSOMAL EPIGALLOCATECHIN-3-GALLATE GEL FORMULATIONS AS AN ANTIOXIDANT AND THERMOGENIC AGENT
}

\author{
WALAA M. SARHAN*, OMNIA SARHAN** \\ ${ }^{*}$ Medical Biochemistry and Molecular Biology Department, Faculty of Medicine, Zagazig University, Zagazig, Egypt, ${ }^{* *}$ Department of \\ Pharmaceutics, Faculty of Pharmacy, Badr University in Cairo, Egypt \\ Email: walaasarhan@hotmail.com \\ Received: 31 Jul 2020, Revised and Accepted: 18 Sep 2020
}

\section{ABSTRACT}

Objective: The aim of this study was to investigate in vitro and in vivo behavior of the prepared ethosomal formulations of green tea extract, which in turn would result in enhancing their therapeutic efficacy as antioxidants and thermogenic agents in obese mice.

Methods: Fat Wistar rats were acclimated for at least $7 \mathrm{~d}$ in environmentally controlled cages, then they were divided into five groups: 1 st received only distilled water, $2^{\text {nd }}$ received an oral dose of green tea extract, in $3^{\text {rd }}$ group green tea extract loaded gel base was applied on the previously shaven dorsal side of rats and in the other 2 groups selected green tea extract loaded Ethosomal gel base were applied on the previously shaven dorsal side of rats. Total antioxidant capacity by ferric reducing ability of plasma (FRAP) method, catalase enzyme activity, malondialdehyde (MDA) and thiobarbituric acid reactive substance (TBARs) levels, and real-time qPCR of UCP2 and 3 were then determined.

Results: Formulation of green tea extract as ethosomal preparations exhibited a controlled release rate due to the reservoir action of ethosomes. The levels of TBARs and MDA were lower in groups supplemented with green tea extracts compared to control group and in groups (3-5) received it transdermal ( $\mathrm{P}<0.0001$ in all 3 groups) was lower than group received it orally with $\mathrm{P}=0.0081$. The messenger RNA levels of UCPs 2 and 3 in $\mathrm{BAT}$ were increased in those 3 groups.

Conclusion: The results support the efficiency of ethosomal gel in penetrating the lipid rich biological membrane. The in vivo study confirms the antioxidant and thermogenic behavior of transdermal applied green tea extract.

Keywords: Bioavailability, Lecithin, Green tea extract, Transdermal, Ethosome, Uncoupling proteins (UCPs) and Real-Time Polymerase Chain Reaction (RT-PCR)

(C) 2020 The Authors. Published by Innovare Academic Sciences Pvt Ltd. This is an open access article under the CC BY license (http://creativecommons.org/licenses/by/4.0/) DOI: http://dx.doi.org/10.22159/ijpps.2020v12i11.39276. Journal homepage: https://innovareacademics.in/journals/index.php/ijpps.

\section{INTRODUCTION}

Thousands of years ago (started in prehistoric times), natural products, such as plants, microorganisms, animals, and marine organisms, have been used to relieve and treat many diseases [1]. The replacements of normally used drugs with natural products, must of course, have presented a tremendous challenge to humans all overages. Green tea (Camellia sinensis) (fam. Theaceae) has been confirmed as safe agent with many benefits as one of the extremely important natural products [2]. Epigallocatechin gallate (EGCG) is the main effective component in green tea leaves extract and is responsible for many health beneficial effects. EGCG has a high antioxidant activity that can provide protection to the body from the risk of cardiovascular diseases, diabetes mellitus, cancer, and neurodegenerative disorders, obesity and exhibits antiinflammatory effects $[3,4]$.

In alkaline media (like small intestine) EGCG is found to be of low absorption rate as less as 5\% of EGCG reach the systemic circulation [5]. The majority amount of EGCG thereafter will be degraded by intestinal micro flora in the colon [6].

To overcome these problems, an alternative drug administration route such as transdermal drug delivery system is used, which can deliver drugs through the skin up to the systemic circulation [7]. This route is characterized by avoidance of gastrointestinal degradation; first pass effect, and drug fluctuations in the blood [8]. To provide optimal antioxidant and thermogenic effects, then the bioactive component of green tea (i.e., EGCG) should penetrate the skin. It is an issue, because of high polarity value of the hydrophilic molecule ( $\log \mathrm{p}=0.48$ ), and a considerable molecular weight of (458.37 da) $[9,10]$.

To overcome this, formulation of green tea leaves extracts into a carrier-based lipid (i.e., ethosomes) is done to enhance its penetration through skin. Ethosomal carriers are systems of soft vesicles. They are mainly composed of (ethanol) and phospholipid (lecithin) at relatively high concentrations, with water as a nonsolvent. Interacting with lipid molecules (found in polar head group region, (ethanol reduces the phase transition temperature (Tm) of the stratum corneum lipids, leading to an increase in fluidity. Moreover, this reaction results in an increase in membrane permeability. In addition, there is an interaction between ethosome itself and the stratum corneum barrier. Ethanol also gives the vesicles flexibility and softness [11]. Ethosomes can deliver hydrophilic and hydrophobic probes to a depth of $170 \mu \mathrm{m}$ with greater intensity than the control systems [12]. However, high cost of phospholipids and their variable purity are sproblems of ethosomes.

Brown adipose tissue (BAT) is an important site for thermogenesis. Due to its high metabolic capability to maintain body temperature in cold conditions or to waste food energy, it is currently considered a novel therapeutic option for obesity management. BAT thermogenesis is mainly dependent on the action of uncoupling proteins (UCPS), which causes conversion of the driving force of adenosine triphosphate $(A T P)$ synthesis into heat via uncoupling the process of oxidative phosphorylation in the mitochondria [13].

The aim of this study was to optimize conditions for encapsulating green tea extract and examine the in vitro and in vivo efficacy of ethosomes on the rat skin when applied as topical formulation. Furthermore, the results should contribute to a better understanding of the antioxidant and thermogenic effects of green tea extract (EGCG) with advancing its bioavailability. In addition, messenger RNA ( $m R N A)$ expression of Uncoupler proteins types II and III genes related to thermogenesis and antioxidant effects were evaluated.

\section{MATERIALS AND METHODS}

\section{Materials}

We purchased Green tea leaves extract (Camellia sinensis) from (Andy Biotech Co. Ltd., China with standard potency $98.4 \%$.). 
Kindly, (Futures manufacture, Egypt) provided us with lectithin and (Sekem development foundation, Egypt) provided us with EGCG standard. A cellophane membrane (Molecular weight cut of 12000 14000) was purchased from United States (USA).

Methods

\section{HPLC determination of EGCG in green tea extract}

EGCG percentage was accurately measured spectrophotometrically by High performance liquid chromatography (HPLC) in green tea extract against EGCG standard [14] at 278 wavelength [15].

\section{Preparation of ethosomes encapsulating green tea extract}

\section{Preparation of Ethosomes}

Ethosomes were prepared by slight modification of cold method [11] Initially Lecithin was taken and dissolved in ethanol by use of magnetic stirrer in completely closed flask at $30^{\circ} \mathrm{C}$. To this solution, $50 \mathrm{mg}$ of the green tea extract dissolved in hot distilled water $\left(30^{\circ} \mathrm{C}\right)$ was added as fine stream by the use of syringe very slowly. The volume was made up using distilled water $\left(30^{\circ} \mathrm{C}\right)$, thereafter whole system was whiskered for $15 \mathrm{~min}$ at $900 \mathrm{rpm}$. Further, it was sonicated for 5-15 min. Finally, the formulations were stored under refrigeration. We prepared 12 batches of ethosomes using varying concentrations of lecithin (1-3\%) and ethanol (10-40\%). (Table 1) The most two stabilized ethosomes with high entrapment efficiency and lower Poly Dispersity Index were selected for the preparation of two individual vesicle incorporated gel formulations and further selected in vivo study.

\section{Characterization of ethosomes}

\section{Morphology and structure of ethosomes}

For visualization of sample by Scanning Electron Microscopy (SEM), one drop of ethosomal system was mounted on a stub covered with a clean glass. The drop was spread out on the glass homogenously. The ethosomal dispersion was spread on the glass slide using a glass rod. Formation of multilamellar vesicles was confirmed by examining the ethosomal suspension under an optical microscope with the magnification power of $100 \mathrm{X}$ (Olympus). Olympus camera was used for Photography.

Table 1: Composition of ethosomal vesicles

\begin{tabular}{|c|c|c|c|}
\hline Formula code & Lecithin \% & Ethanol: water & Green tea extract (mg) \\
\hline T1 & 1 & $10: 90$ & 50 \\
\hline $\mathrm{T} 2$ & 1 & $20: 80$ & 50 \\
\hline $\mathrm{T} 3$ & 1 & $30: 70$ & 50 \\
\hline $\mathrm{T} 4$ & 1 & $40: 60$ & 50 \\
\hline $\mathrm{T} 5$ & 2 & $10: 90$ & 50 \\
\hline $\mathrm{T} 6$ & 2 & $20: 80$ & 50 \\
\hline $\mathrm{T} 7$ & 2 & $30: 70$ & 50 \\
\hline $\mathrm{T} 8$ & 2 & $40: 60$ & 50 \\
\hline Т9 & 3 & $10: 90$ & 50 \\
\hline $\mathrm{T} 10$ & 3 & $20: 80$ & 50 \\
\hline $\mathrm{T} 11$ & 3 & $30: 70$ & 50 \\
\hline $\mathrm{T} 12$ & 3 & $40: 60$ & 50 \\
\hline
\end{tabular}

12 batches of ethosomes were prepared using varying concentrations of lecithin (1-3\%) and ethanol (10-40\%).

\section{Determination of entrapment efficiency (EE \%)}

The entrapment efficiencies of ethosomal preparations were determined by HPLC after dispersion in phosphate buffer. The ethosomal dispersion obtained was centrifuged at $10000 \mathrm{rpm}$. Then, supernatant was assayed for free drug [16].

\section{Particle size and polydispersity index}

Particle size and index polydispersity were measured using a particle size analyzer. The measurements were repeated. The polydispersity index was conducted to evaluate the particle distribution of ethosomes [17-19].

\section{In vitro drug release studies}

The in vitro permeation behaviour of green tea extract from ethosomal formulations was investigated using diffusion cell model. The diffusion cell was consisted of a cellophane membrane filled with ethosomal preparation, which was placed in a receptor compartment containing phosphate buffer agitated at $100 \mathrm{rpm}$ at $37 \pm 0.5{ }^{\circ} \mathrm{C}$. An aliquot of $2 \mathrm{ml}$ sample was withdrawn at predetermined time intervals over $24 \mathrm{~h}$ and replaced immediately with an equal volume of fresh diffusion medium. The samples were filtered and analyzed using HPLC [20-23].

\section{In vivo study}

\section{Grouping and dose administration}

We used Fat Wistar rats $(250 \pm 50$ g) for our current study (supplied by the animal house in the faculty of medicine, Zagazig University). Ethical clearance for our study was obtained from the Institutional Review Board (IRB/08/2019), Zagazig University, Egypt. Rats were adapted for $7 \mathrm{~d}$ in environmentally controlled $\left(23{ }^{\circ} \mathrm{C} \pm 1{ }^{\circ} \mathrm{C}\right.$ and equally half day dark/light cycle) cages, with free consumption of standard food and water and fasted overnight before the experiments. We divided them into 5 groups (ten rats per group):

\section{- $1^{\text {st }}$ GROUP (control): were given distilled water only}

- $2^{\text {nd }}$ GROUP (standard): were given (by oral feeding needles) oral dose of green tea extract.

- $3^{\text {rd }}$ GROUP: we applied loaded gel base with green tea extract on the shaven dorsal side of rats.

- $4^{\text {th }}$ and $5^{\text {th }}$ GROUPS: we applied dose equivalent to $100 \mathrm{mg} / \mathrm{kg}$ body weight of selected green tea extract loaded Ethosomal gel base (T10 and T12) on shaven dorsal side of rats [24].

Animals were sacrificed after daily dosing for $7 \mathrm{~d}$. A central longitudinal incision was made in the abdominal wall and blood samples were collected by cardiac puncture. Blood samples were centrifuged at $1500 \times g$ for $20 \mathrm{~min}$ at $4{ }^{\circ} \mathrm{C}$ and the plasma was separated and stored at $-20{ }^{\circ} \mathrm{C}$ until analyzed. The BAT was harvested, frozen immediately in liquid nitrogen, and stored at $-70^{\circ} \mathrm{C}$. Liver from each animal was excised and its homogenate was prepared and centrifuged for $5 \mathrm{~min}$ at $4{ }^{\circ} \mathrm{C}$. The supernatant obtained was further used for antioxidant assay [25]. Different specimens of the liver, kidney and brain were embedded in paraffin blocks, stained and observed for any changes under light microscope [26].

\section{Assay of total antioxidant capacity (TAC)}

We measured total antioxidant capacity by ferric reducing ability of plasma (FRAP) method, which is based on the capability of plasma to reduce $\mathrm{Fe}^{3+}$ to $\mathrm{Fe}^{2+}$ in the presence of TPTZ (2,4,6-tripyridyl-s-trlazine) [27].

\section{Determination of catalase activity}

The activity of catalase (CAT) was assayed following (Pari and Latha) method [28].

\section{Estimation of lipid peroxidation}

We determined levels of malondialdehyde (MDA) and thiobarbituric acid reactive substance (TBARs) production by (Draper and Hadley) method [29]. 


\section{Real-time qPCR}

Total RNA was extracted from BAT using TRIzol Reagent (Invitrogen, Carlsbad, CA, USA). The complementary DNA ( $c D N A)$ was prepared from $1 \mu \mathrm{g} R N A$ using Maxime RT PreMix (iNtRON). After cDNA synthesis, $2 \mu$ l of first-strand $c D N A$ was used for real time $P C R(R T-P C R)$ in $20 \mu \mathrm{l}$ reactions containing $10 \mathrm{ul}$ of Universal SYBR Green PCRMaster Mix (Qiagen, Chatsworth, CA, USA), $1 \mathrm{ul}$ of each primer and 4 ul PCR grade water in thermal cycler (DTlite 4 DNA-TECHNOLOGY, Russia). The sequences of the sense and antisense primers used for amplification are shown in table 2 .

Table 2: Primers used for the real-time quantitative polymerase chain reaction

\begin{tabular}{lll}
\hline Gene & Sense primer $\left(5^{\prime}-\mathbf{3}^{\prime}\right)$ & Antisense primer $\left(\mathbf{5}^{\prime} \mathbf{- 3}\right)$ \\
\hline UCP-2 & GACCTATGACCTCATCAAGG & ATAGGTGACGAACATCACCACG \\
UCP-3 & ATGGACGCCTACAGAACCAT & TACGAACATCACCACGTTCC \\
$\beta$-actin & AGAGCTACGAGCTGCCTGAC & AGCACTGTGTTGGCGTACAG \\
\hline
\end{tabular}

The sequences of the sense and antisense primers for UCP-2, UCP-3 and $\beta$-actin

The $\Delta \Delta$ Ct method was used for measuring relative quantification [30]. We determined the $\Delta \Delta \mathrm{Ct}$ value for each sample by calculation of the difference between the target gene $\mathrm{Ct}$ value and the $\beta$-actin $\mathrm{Ct}$ value as a reference gene. The normalized level of the target gene expression in each sample was calculated using the formula $2-\Delta \Delta \mathrm{Ct}$ Values were expressed as fold change relative to the control group.

\section{Statistical analysis}

All data are presented as mean \pm SD (standard deviation). We conducted Statistical analysis using (SPSS) (version 17; IBM Corporation, Armonk, NY, USA). $P<0.05$ was considered as an indication of a statistically significant difference.

\section{RESULTS}

\section{HPLC determination of EGCG in green tea extract}

Amount of EGCG presented in green tea extract was measured at 278 wavelengths; this wavelength was advised by Huo et al. [31]. By optimizing HPLC conditions, the concentration of EGCG in the working green tea extract sample solution was determined (54.24 \%) (fig. 1). To ensure the presence of suitable amount of $E G C G$ within the extract with further dilutions, we constructed a calibration curve (fig. 2).

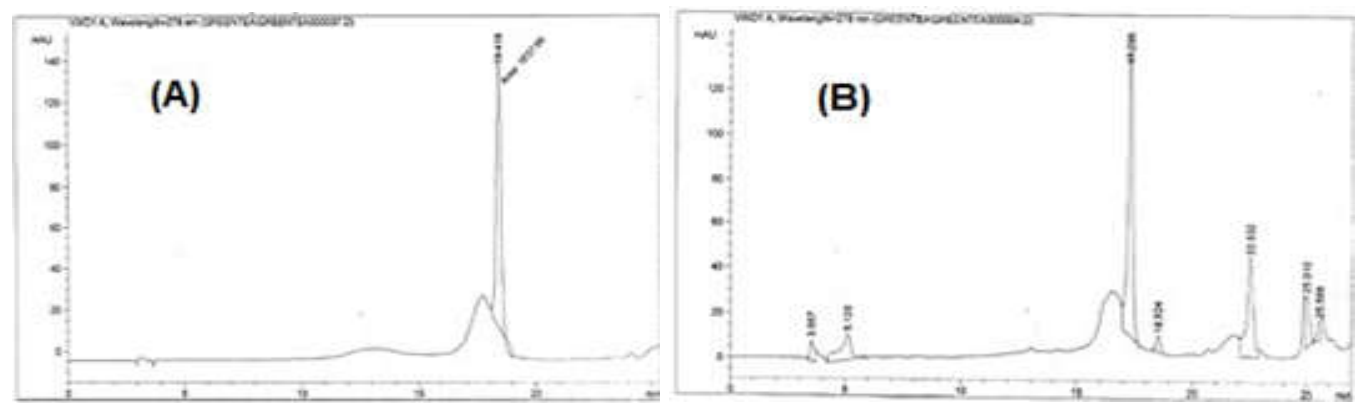

Fig. 1: HPLC profile of Green tea extracts (a) chromatogram of EGCG standard and (b) chromatogram of green tea extract, by optimizing HPLC conditions, the concentration of EGCG in the working green tea extract sample solution was determined (54.24 \%)

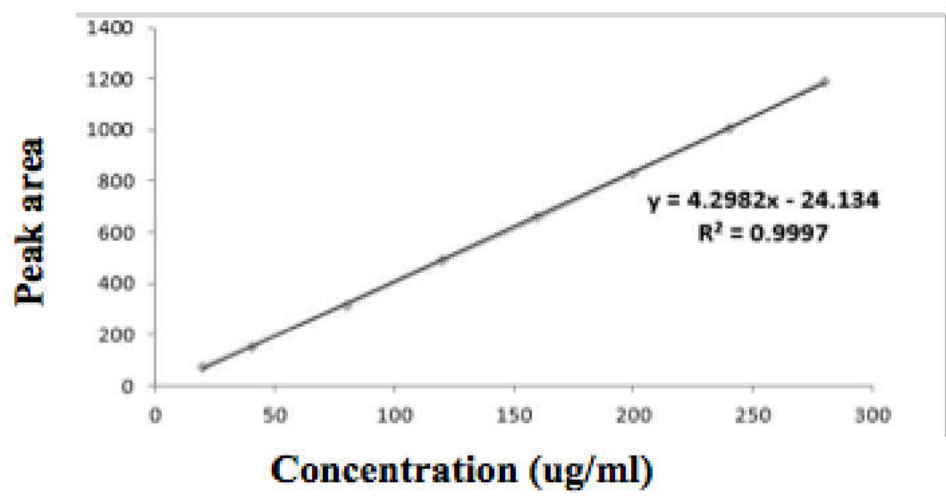

Fig. 2: Calibration curve of EGCG in green tea extract, to ensure the presence of a suitable amount of EGCG within the extract with further dilutions, we constructed a calibration curve

\section{Preparation of ethosomes encapsulating green tea extract}

Irrespective of whether transdermal absorption has a local effect or systemic action, the drug should pass through the stratum corneum. Because of the barrier effect of stratum corneum, the majority of drugs cannot give their required therapeutic effect when applied topically. Recently, ethosomes are widely used for transdermal delivery because they not only easily pass through the skin but also increase the accumulation of drug in the skin. Dayan, N., and Touitou, E., concluded that when compared with normal 
liposomethe, steady-state transdermal rate of trihexyphenidyl hydrochloride ethosomes composed of phospholipid, ethanol, and water increased by 87 fold [32]. In our current study, to enhance the transdermal penetration of green tea extract, ethosomal formulations were prepared and they were further incorporated into gels.

Ethosomal dispersal was enhanced with increasing amounts of lecithin concentration $(1,2$, and $3 \%)$ and ethanol $(10,20,30$, and
$40 \%)$. In all these dispersions, ethanol concentration with different percentages induced white milky suspensions without any significant differences under the macroscopic view. As one of the broad parameters for the evaluation of prepared ethosomes quality according to the basis of their particle size distribution, Poly Dispersity Index (PDI) was including with a value of $0-1$ as reference. The preparations presenting PDI in this range were then evaluated based on their drug entrapment efficiency and vesicular size (table 3). PDI index range was (0.043-0.282).

Table 3: Entrapment efficiency, vesicle size and polydispersity index of the various ethosomal preparations

\begin{tabular}{lllll}
\hline F & Drug content \% mean \pm SD & EE \% mean \pm SD & Vesicle size (nm) mean \pm SD & Polydispersity index (PDI) mean \pm SD \\
\hline T1 & $63.77 \pm 2.49$ & $60.93 \pm 2.34$ & $184.22 \pm 2.33$ & $0.067 \pm 0.003$ \\
T2 & $71.08 \pm 1.37$ & $64.51 \pm 0.98$ & $134.82 \pm 0.72$ & $0.049 \pm 0.001$ \\
T3 & $73.18 \pm 0.94$ & $69.21 \pm 1.33$ & $112.65 \pm 1.56$ & $0.038 \pm 0.002$ \\
T4 & $76.4 \pm 0.81$ & $71.39 \pm 1.52$ & $100.23 \pm 1.3$ & $0.043 \pm 0.003$ \\
T5 & $79.29 \pm 2.01$ & $73.94 \pm 2.27$ & $222.32 \pm 0.98$ & $0.210 \pm 0.019$ \\
T6 & $83.4 \pm 0.11$ & $78.82 \pm 0.42$ & $200.81 \pm 1.44$ & $0.088 \pm 0.008$ \\
T7 & $85.46 \pm 1.61$ & $79.9 \pm 2.3$ & $169.2 \pm 2.74$ & $0.067 \pm 0.005$ \\
T8 & $87.14 \pm 0.67$ & $81.59 \pm 1.68$ & $145.72 \pm 1.07$ & $0.058 \pm 0.002$ \\
T9 & $89.78 \pm 0.3$ & $85.63 \pm 1.03$ & $314.04 \pm 1.32$ & $0.279 \pm 0.013$ \\
T10 & $90.9 \pm 1.22$ & $87.91 \pm 2.69$ & $309.68 \pm 0.78$ & $0.121 \pm 0.011$ \\
T11 & $91.93 \pm 0.52$ & $88.5 \pm 1.94$ & $299.5 \pm 0.99$ & $0.282 \pm 0.024$ \\
T12 & $93.32 \pm 1.54 *$ & $287.06 \pm 1.01$ & $0.117 \pm 0.029$ \\
\hline
\end{tabular}

Values are presented as mean \pm SD, PDI index range was $(0.043-0.282)$, formulation $\mathrm{T} 12 *(93.32 \%)$ showed maximized drug content with maximal ethanol content and increased lecithin concentration.

Shape and size of the vesicle are critical factors in transdermal drug delivery system therapeutic performance. In our current study, phase-contrast microscopy showed the surface morphology of ethosomes (fig. 3).

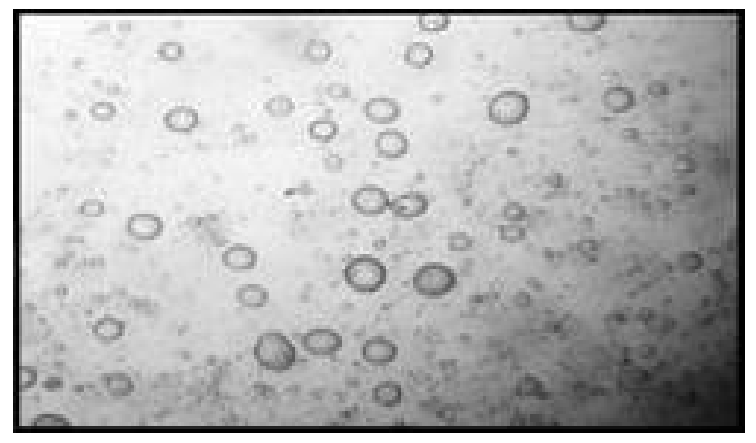

Fig. 3: Microscopical image of ethosomal dispersion

Phase contrast microscopy showed the surface morphology of ethosomes

Minimum and maximum vesicle sizes were observed to be 100.23 $\mathrm{nm}$ and $314.04 \mathrm{~nm}$, respectively, depending on the concentration of ethanol and lecithin. The vesicles size was found to increase with lecithin concentration increase from (1-3\%), while it was inversely related to concentration of alcohol (higher alcohol concentrations accompanied with lower vesicle size). This observation agreed with the Elsayed et al. findings [33] that higher concentration of ethanol allows a surface negative net charge to the vesicular systems by surface characteristics manipulation, this leads to a decrease in vesicles size. When we kept lecithin amount at $1 \%$ while increased ethanol concentration from $10 \%$ to $40 \%$, a decrease in vesicles size from (184.22 to $100.23 \mathrm{~nm}$ ) was observed. Likewise, vesicles size decreased from (222.32 to 145.72) $\mathrm{nm}$ and from (314.04 to $287.06 \mathrm{~nm}$ ) with lecithin concentration $2 \%$ and $3 \%$, respectively and with the same increase in ethanol concentration (table 3).

Entrapment efficiency is used as a quality parameter, which has a direct effect on the delivery potential of the vesicular systems and to be determined in the formulated ethosomal vesicles, the drug content in each preparation was to be determined first. Drug content ranged from $63.77 \pm 2.49 \%$ to $93.32 \pm 1.54 \%$ that shows good capacity of formulation to hold the drug. Formulation T12 (93.32\%) showed maximized drug content with maximal ethanol content and increased lecithin concentration.

Ethanol and lecithin amounts and concentrations had a positive effect on the entrapment of the herbal extract inside lipid vesicles. Entrapment efficiency was showed to be $87.91 \%$ with $20 \%$ ethanol and $3 \%$ lecithin formulation (T10), while increased to $88.5 \%$ and $90.11 \%$ with alcohol concentration increase to $30 \%$ and $40 \%$, respectively, and lecithin concentration kept unchanged at 3\% (table 3 ). This increase is probably due to accelerated green tea extract solubility in water present in the ethosomal core. Concentration of ethanol in the ethosome system should be maintained below $45 \%$. In our study, when concentration exceeded $40 \%$, drug leakage from the lipid bilayer started, leading to decreased entrapment percentage. Our data agreed with Paolino et al. findings and conclusion [34].

\section{In vitro drug release studies through cellophane membrane}

The initial drug release should be fast enough to guarantee the maintenance of therapeutic drug levels in vivo in a timely way [35, 36].

As shown in (fig. 4), the release of all prepared ethosomal formulations after $24 \mathrm{~h}$ exceeded $50 \%$. Green tea extract formulated as ethosomal preparations showed a controlled release rate due to ethosomes' reservoir action. The impulse effect over the first six hours was clearly observed, with a following step of slower release, this finding might be linked with the feature of the bilayer or ethosomal structure [37-39]. The release rate then increased gradually with ethanol concentration increasing from 20 to $40 \%$. Moreover, a higher released amount was observed with increasing lecithin concentration which might be related to increased drug solubility [40] as well as increased lipid bilayer fluidity, which leads to drug release improvement $[41,42]$. 


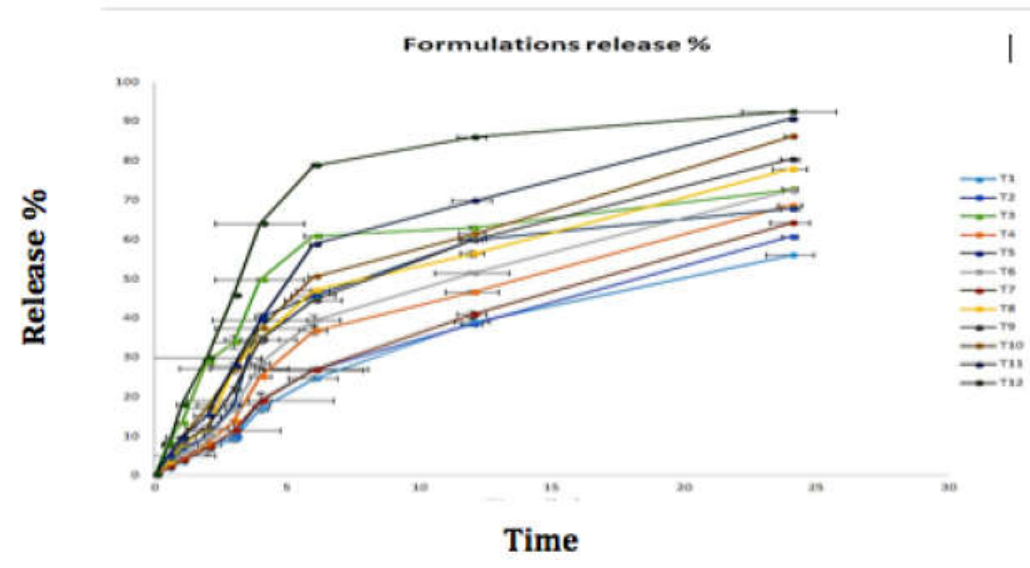

Fig. 4: Release profiles of all the prepared ethosomes (each value was an average of three measurements \pm SD

The release of all prepared ethosomal formulations after $24 \mathrm{~h}$ exceeded $50 \%$. Green tea extract formulated as ethosomal preparations showed a controlled release rate due to ethosomes' reservoir action.

Therefore, both T10 and T12 formulations were selected as the optimized green tea extract ethosomal formulations, that showed higher EE \%, lower polydispersity index, as well as optimum release, consequently increasing penetrability and bioavailability [43].

\section{In vivo study}

Green tea extracts supplementation effect on ferric reducing ability of plasma (table 4), demonstrates the variation between the $1^{\text {st }}$ group (control) and the others. FRAP level was noticed to be increased in groups supplemented with green tea extracts compared to control. It was higher in all transdermal receiving $\left(3^{\text {rd }}, 4^{\text {th }}\right.$, and $\left.5^{\text {th }}\right)$ groups $\left(\mathrm{P}<0.0001\right.$ in all 3 groups and $95 \%$ CI 0.7915 to 1.1485 in $4^{\text {th }}$ group) than the $2^{\text {nd }}$ group (orally receiving) with $\mathrm{P}=0.0035$ and $95 \%$ CI 0.1758 to 0.7642 .

Table 4: Ferric reducing ability of plasma and changes in the activity of catalase and in TBARs and MDA production in different study groups

\begin{tabular}{lllll}
\hline Groups & FRAP $(\mathbf{m g} / \mathbf{m l})$ mean \pm SD & $\begin{array}{l}\text { Catalase activity (Units/ml) } \\
\text { mean } \pm \text { SD }\end{array}$ & $\begin{array}{l}\text { TBARs } \\
\text { (nmol/ml) mean } \pm \text { SD }\end{array}$ & $\begin{array}{l}\text { MDA } \\
\text { (umol/l) mean } \pm \text { SD }\end{array}$ \\
\hline Control group & $1.13 \pm 0.19$ & $2.4 \pm 0.29$ & $5.04 \pm 0.78$ & $3.5 \pm 0.21$ \\
Standard group & $1.65 \pm 0.40$ & $4.075 \pm 0.56$ & $4.2 \pm 0.34$ & $2.4 \pm 0.09$ \\
Group III & $1.9 \pm 0.15$ & $5.125 \pm 0.26$ & $2.6 \pm 1.1$ & $2.18 \pm 0.06$ \\
Group IV & $2.1 \pm 0.19^{*}$ & $5.075 \pm 0.23 * *$ & $3.01 \pm 0.34^{*}$ & $2.21 \pm 0.043$ \\
Group V & $2.1 \pm 0.29^{*}$ & $5.425 \pm 0.46$ & $3.2 \pm 1.01^{*}$ & $2.14 \pm 0.05$ \\
\hline
\end{tabular}

Values are presented as mean $\pm \mathrm{SD}^{*}$ : statistically significant compared to corresponding value of other groups $(\mathrm{P}<0.05)$

Additionally, Green tea extracts supplementation effect on the activity of catalase enzyme (table 4), demonstrates the variation between the $1^{\text {st }}$ group (control) and the others. CAT enzyme activity levels were noticed to be influenced in groups supplemented with green tea extracts compared to control. It was better in all transdermal receiving $\left(3^{\text {rd }}, 4^{\text {th }}\right.$ and $\left.5^{\text {th }}\right)$ groups $(\mathrm{P}<0.0001$ in all 3 groups and $95 \%$ CI 2.6387 to 3.3613 in group 5) than the $2^{\text {nd }}$ group (orally receiving) with $\mathrm{P}<0.0001$ and $95 \%$ CI 1.5810 to 2.4190 . In the current study, we confirmed that the activity of catalase enzyme is unregulated by catechins.

Also, Green tea extracts supplementation effect on production of thiobarbituric acid reactive substance (TBARs) and malondialdehyde $(M D A)$ (table 4), demonstrates the variation between the $1^{\text {st }}$ group (control) and the others. TBARs and MDA levels were noticed to be lower in groups supplemented with green tea extracts compared to control group. Additionally, it was lower in all transdermal receiving $\left(3^{\text {rd }}, 4^{\text {th }}\right.$, and $\left.5^{\text {th }}\right)$ groups $(\mathrm{P}<0.0001$ in all 3 groups and $95 \%$ CI3.2959 to- 1.5041 in-group 3 ) than the $2^{\text {nd }}$ group (orally receiving) with $\mathrm{P}=0.0081$ and $95 \%$ CI-1.3653 to- 0.2347 .

On observation of plasma lipid profile changes (table 5), there was a decrease in cholesterol concentration by $12 \%$ in the $2^{\text {nd }}$ group supplemented with green tea extracts orally compared to the $1^{\text {st }}$ control group, and by $20 \%, 10 \%$ and $22 \%$ in transdermal receiving $\left(3^{\text {rd }}, 4^{\text {th }}\right.$, and $\left.5^{\text {th }}\right)$ respectively. Regarding HDL level, no effect was observed in $2^{\text {nd }}$ group (orally receiving) compared to control group. However, it increased in all transdermal receiving $\left(3^{\text {rd }}, 4^{\text {th }}\right.$, and $\left.5^{\text {th }}\right)$ groups in relation to control group. The Triglycerides, LDL and VLDL levels were decreased in all green tea extract supplemented groups compared to control group.

Table 5: Changes in lipid profile in different study groups

\begin{tabular}{|c|c|c|c|c|c|}
\hline Groups & $\begin{array}{l}\text { Cholesterol }(\mathrm{mg} / \mathrm{dl}) \\
\text { mean } \pm \text { SD }\end{array}$ & $\begin{array}{l}\text { HDL } \\
(\mathrm{mg} / \mathrm{dl}) \text { mean } \pm S D\end{array}$ & $\begin{array}{l}\text { Triglycerides }(\mathrm{mg} / \mathrm{dl}) \\
\text { mean } \pm \text { SD }\end{array}$ & $\begin{array}{l}\text { LDL } \\
(\mathrm{mg} / \mathrm{dl}) \text { mean } \pm S D\end{array}$ & $\begin{array}{l}\text { VLDL } \\
(\mathrm{mg} / \mathrm{dl}) \text { mean } \pm S D\end{array}$ \\
\hline Control group & $110 \pm 5$ & $58 \pm 3$ & $159 \pm 3$ & $60 \pm 0.2$ & $10 \pm 3$ \\
\hline Standard group & $91 \pm 3$ & $58 \pm 3$ & $126 \pm 3$ & $50 \pm 0.9$ & $12 \pm 5$ \\
\hline Group III & $89 \pm 2$ & $64 \pm 3$ & $102 \pm 5$ & $43 \pm 0.9$ & $13 \pm 3.2$ \\
\hline Group IV & $90 \pm 2.5$ & $60 \pm 2$ & $112 \pm 3$ & $35 \pm 1$ & $11 \pm 3$ \\
\hline Group V & $86 \pm 3$ & $62 \pm 1.6$ & $118 \pm 2.5$ & $33 \pm 1.6$ & $9 \pm 4$ \\
\hline
\end{tabular}

Values are presented as mean \pm SD: HDL levels were increased in all transdermal-receiving $\left(3^{\text {rd }}, 4^{\text {th }}\right.$, and $\left.5^{\text {th }}\right)$ groups in relation to control group. The 
Triglycerides, LDL and VLDL levels were decreased in all green tea extract supplemented groups compared to control group.
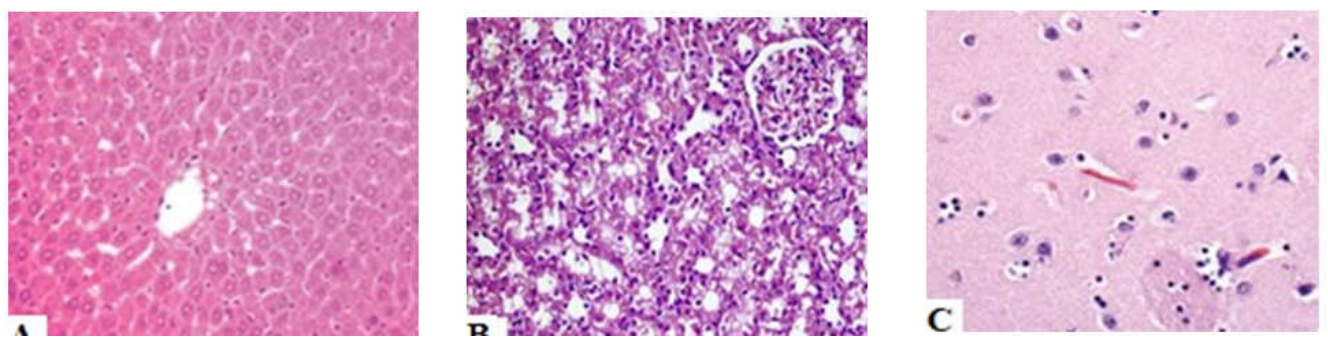

Fig. 5: Different histological specimens of experimental rats

Histopathological observation of tissues of various organs (brain liver, and kidney) after administration of green tea extract (orally and transdermal) (fig. 5) showed no changes in the organs' tissues and cells of rats'specimens. Confirming that short time periods and such doses of oral and/or transdermal administration of green tea extract formulations doesn't cause any toxicity to brain, liver, nor kidney of the tested rats.

Fig. different histological specimens of experimental rats $(\mathrm{H}$ and $\mathrm{E}$ $\times 400$ ) (a) liver, (b) kidney and (c) brain, show normal tissues with non-remarkable changes with control specimens.

To determine the relationship between EGCG supplementation and anti-oxidation or thermogenesis, the mRNA levels of UCP2 and UCP3 were measured in BAT. Transdermal administration of green tea extract formulations significantly increased the mRNA levels of UCP2 and UCP3 in groups 3-5 compared with those in the control group. Values for the $4^{\text {th }}$ group are expressed as the fold change compared with those for the control group (mean $\pm S D, n=10)$. $\mathrm{p}<0.001$ vs. control group.

Aster Spathulifolius extract (when administered orally) causes increase in the mRNA synthesis of genes like CPT1, UCP2, and UCP3 in the muscle of induced obese rats, which are involved in thermogenesis. We found that the expression of UCP2 and UCP3 in BAT were up-regulated significantly upon transdermal administration of green tea extract formulations (fig. 6, 7).

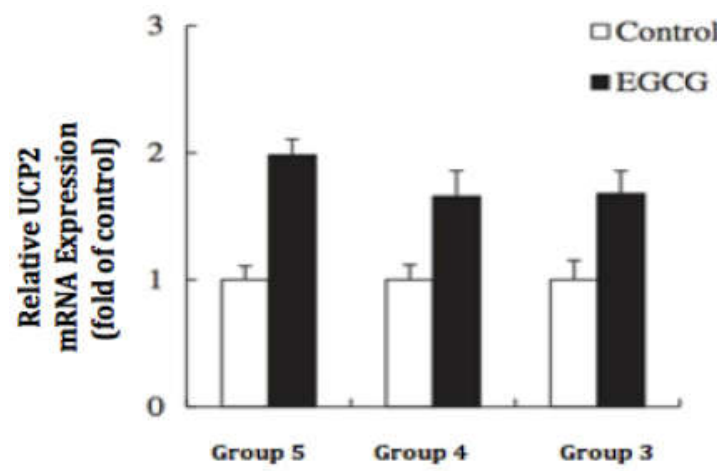

Fig. 6: Relative messenger RNA (mRNA) levels of UCP-2 gene, relative messenger RNA (mRNA) levels of UCP-2 gene in brown adipose tissue of rat in Epigallocatechin-3-gallate (EGCG) groups in relation to control groups

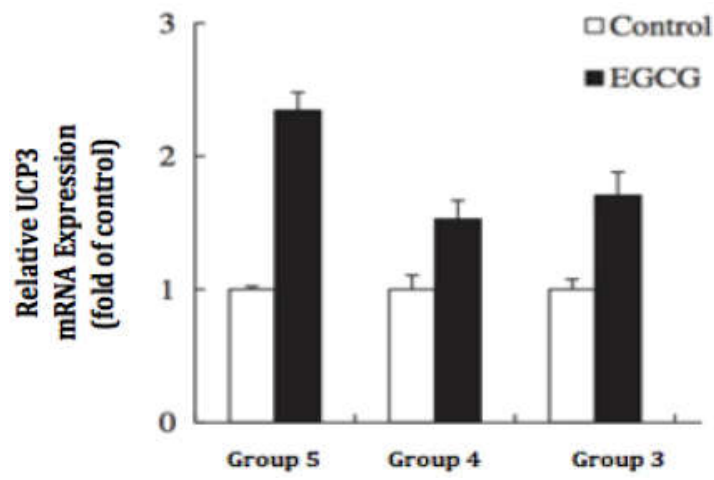

Fig. 7: Relative messenger RNA (mRNA) levels of UCP-3 gene, relative messenger RNA (mRNA) levels of UCP-3 gene in brown adipose tissue of rat in epigallocatechin-3-gallate (EGCG) groups in relation to control groups

DISCUSSION

In the present study, we found that FRAP was higher in all transdermal receiving $\left(3^{\text {rd }}, 4^{\text {th }}\right.$, and $\left.5^{\text {th }}\right)$ groups $(\mathrm{P}<0.0001$ in all 3 
groups and $95 \%$ CI 0.7915 to 1.1485 in $4^{\text {th }}$ group) than the $2^{\text {nd }}$ group (orally receiving) with $\mathrm{P}=0.0035$ and $95 \%$ CI 0.1758 to 0.7642 . Forester and lambert [44] and Chacko et al. [45] are in line with our findings.

CAT enzyme activity levels were noticed to be influenced in groups supplemented with green tea extracts compared to control. It was better in all transdermal receiving $\left(3^{\text {rd }}, 4^{\text {th }}\right.$, and $\left.5^{\text {th }}\right)$ groups $(\mathrm{P}<0.0001$ in all 3 groups and $95 \%$ CI 2.6387 to 3.3613 in group 5) than the $2^{\text {nd }}$ group (orally receiving) with $\mathrm{P}<0.0001$ and $95 \% \mathrm{CI}$ 1.5810 to 2.4190 . In the current study, we confirmed that the activity of the catalase enzyme is unregulated by catechins. Our results agreed with Li et al. [46] and Nelson et al. [47], However, opposed Pal et al. [48] and Chance et al. [49] findings, probably due to green tea extract use on induced injured animals.

Also, TBARs and MDA levels were noticed to be lower in groups supplemented with green tea extracts compared to control group. Additionally, it was lower in all transdermal receiving $\left(3^{\text {rd }}, 4^{\text {th }}\right.$, and $\left.5^{\text {th }}\right)$ groups $(\mathrm{P}<0.0001$ in all 3 groups and 95\% CI-3.2959 to- 1.5041 ingroup 3) than the $2^{\text {nd }}$ group (orally receiving) with $P=0.0081$ and $95 \%$ CI-1.3653 to-0.2347. Our findings are in line with Mohamadin et al., Awoniyi et al., Messarah et al., and Prabakar et al. [50-53] results.

On observation of plasma lipid profile changes, there was a decrease in cholesterol concentration by $12 \%$ in the $2^{\text {nd }}$ group supplemented with green tea extracts orally compared to the $1^{\text {st }}$ control group, and by $20 \%, 10 \%$ and $22 \%$ in transdermal receiving $\left(3^{\text {rd }}, 4^{\text {th }}\right.$, and $\left.5^{\text {th }}\right)$ respectively. Regarding HDL level, no effect was observed in $2^{\text {nd }}$ group (orally receiving) compared to control group.

However, increased in all transdermal-receiving $\left(3^{\text {rd }}, 4^{\text {th }}\right.$, and $\left.5^{\text {th }}\right)$ groups in relation to control group. The Triglycerides, LDL and VLDL levels were decreased in all green tea extract supplemented groups compared to control group. Our results are consistent with the results of Basu et al., Bornhoeft et al., Cunha et al., and Hassan et al. [54-57]. However, no effect of green tea supplementation on plasma lipid profile was the conclusion of Princen et al., Erba et al. and Fukino et al. [58-60], which may be dose dependent effect.

Dulloo et al. [61] found an increase in the 24h energy expenditure by supplementation of green tea extract in humans. Subsequently, they reported an enhancement in the oxygen uptake rate for $B A T$ by giving an ethanol extract of green tea, indicating the occurrence of BAT thermogenesis [62]. Green tea extract increases BAT thermogenesis via $\beta$-adrenoreceptor stimulation [63]. Green tea EGCG (via stimulating UCP2 expression in WAT) was observed to decrease diet-induced obesity [64]. Aster Spathulifolius extract (when administered orally) causes increase in the mRNA synthesis of genes like CPT1, UCP2, and UCP3 in the muscle of induced obese rats, which are involved in thermogenesis [65]. We found that expression of UCP2 and UCP3 in BAT were up regulated significantly upon transdermal administration of green tea extract formulations.

\section{CONCLUSION}

Based on observations of present study, it can be concluded that a combination of $40 \%$ ethanol, $3 \%$ lecithin and $75 \%$ green tea extract $(50 \mathrm{mg}$ ) can be used for the preparation of ethosomes with good entrapment efficiency. The in vitro release efficiency of ethosomal gel was found up to $92.49 \%$, which support the potential of these carriers in penetrating the lipid rich biological membrane. The in vivo study confirms the antioxidant behavior of transdermal applied green tea extract. The findings suggest that EGCG may play important roles in regulating $B A T$ thermogenesis and antioxidant effects for improving obesity. The present study revealed ethosomal gel as an efficient carrier for herbal extract.

\section{AUTHORS CONTRIBUTIONS}

Both authors designed for the study collected the data, analyzed, and wrote manuscripts. The first author was responsible for all the biochemical and molecular procedures. The second author performed all pharmaceutical experiments. All authors are responsible for financial support to complete the research.

\section{ABBREVIATIONS}

ATP-Adenosine triphosphate, BAT-Brown adipose tissue, CATCatalase activity, cDNA-Complementary DNA, CI-Confidence interval, EE-Entrapment efficiency, EGCG-Epigallocatechin gallate, FRAPFerric-reducing ability of plasma, HDL-High Density Lipoprotein, HPLC-High performance liquid chromatography, LDL-Low Density Lipoprotein, MDA-Malondialdehyde, PDI-Poly Dispersity Index, RNA-Ribonucleic acid, RT-PCR-Real Time Polymerase Chain Reaction, SD-Standard deviation, SEM-Scanning Electron Microscopy, TAC-Total antioxidant capacity, TBARs-Thiobarbituric acid reactive substance, Tm-Transition temperature, TPTZ-2,4,6tripyridyl-s-trlazine, UCPs-Uncoupling proteins, VLDL-Very LowDensity Lipoprotein

\section{AUTHORS CONTRIBUTIONS}

All the authors have contributed equally.

\section{CONFLICT OF INTERESTS}

\section{Declared none}

\section{REFERENCES}

1. Fabricant DS, Farnsworth NR. The value of plants used in traditional medicine for drug discovery. Environ Health Persp 2001;109(Suppl 1):69-75.

2. Namita P, Mukesh R, Vijay KJ. Camellia sinensis (green tea): a review. Glob J Pharmacol 2012;6:52-9.

3. Anand J, Upadhyaya B, Rawat P, Rai N. Biochemical characterization and pharmacognostic evaluation of purified catechins in green tea (Camellia sinensis) cultivars of India. 3 Biotech 2015;5:285-94.

4. Sharangi AB. Medicinal and therapeutic potentialities of tea (Camellia sinensis L.)-a review. Food Res Int 2009;42:529-35.

5. Legeay S, Rodier M, Fillon L, Faure S, Clere N. Epigallocatechin gallate: a review of its beneficial properties to prevent metabolic syndrome. Nutrients 2015;7:5443-68.

6. Mereles D, Hunstein W. Epigallocatechin-3-gallate (EGCG) for clinical trials: more pitfalls than promises? Int J Mol Sci 2011;12:5592-603.

7. Anwar EF, Utami TD, Ramadon DE. Transfersomal gel containing green tea (Camellia sinensis L. Kuntze) leaves extract: increasing in vitro penetration. Asian J Pharm Clin Res 2017;10:294-8.

8. Ramadon D, Goldie AW, Anwar E. Novel transdermal ethosomal gel containing green tea (Camellia sinensis L. Kuntze) leaves extract: formulation and in vitro penetration study. J Young Pharm 2017;9:336.

9. Patel A, Velikov K. Non-covalent interactions of green tea polyphenol: source of novel colloidal structures. In green tea: varieties, production and health benefits. Nova Biomedical; 2013. p. $151-66$.

10. Tanwar H, Sachdeva R. Transdermal drug delivery system: a review. Int J Pharm Sci Res 2016;7:2274.

11. Touitou E, Dayan N, Bergelson L, Godin B, Eliaz M. Ethosomesnovel vesicular carriers for enhanced delivery: characterization and skin penetration properties. J Controlled Release 2000;65:403-18.

12. Mishra D, Dubey V, Asthana A, Saraf DK, Jain NK. Elastic liposomes mediated transcutaneous immunization against Hepatitis B. Vaccine 2006;24:4847-55.

13. Ricquier D, Casteilla L, Bouillaud F. Molecular studies of the uncoupling protein. FASEB J 1991;5:2237-42.

14. Avadhani KS, Amirthalingam M, Reddy MS, Udupa N, Mutalik S. Development and validation of RP-HPLC method for estimation of Epigallocatechin-3-gallate (EGCG) in lipid-based nanoformulations. Res J Pharm Tech 2016;9:725-30.

15. Roman MC, Hildreth J, Bannister S. Determination of catechins and caffeine in camillia sinensis raw materials, extracts, and dietary supplements by HPLC-uv: single-laboratory validation. J AOAC Int 2013;96:933-41.

16. Malakar J, Sen SO, Nayak AK, Sen KK. Formulation, optimization and evaluation of transferosomal gel for transdermal insulin delivery. Saudi Pharm J 2012;20:355-63.

17. Duangjit $\mathrm{S}$, Opanasopit $\mathrm{P}$, Rojanarata $\mathrm{T}$, Ngawhirunpat $\mathrm{T}$. Evaluation of meloxicam-loaded cationic transfersomes as 
transdermal drug delivery carriers. AAPS PharmSciTech 2013;14:133-40.

18. Mitkari BV, Korde SA, Mahadik KR, Kokare CR. Formulation and evaluation of topical liposomal gel for fluconazole. Indian J Pharm Educ Res 2010;44:324-33.

19. Setyawati DR, Surini S, Mardliyati E. Optimization of luteolinloaded transfersome using response surface methodology. Int J Appl Pharm 2017;9:107-11.

20. Fasinu P, Choonara YE, Kumar P, Du Toit LC, Bijukumar D, Khan $\mathrm{RA}$, et al. Enhancement of the oral bioavailability of felodipine employing 8-arm-poly (ethylene glycol): in vivo, in vitro and in silico evaluation. AAPS PharmSciTech 2017;18:617-28.

21. Abdelrahman AA, Salem HF, Khallaf RA, Ali AM. Modeling, optimization, and in vitro corneal permeation of chitosanlomefloxacin $\mathrm{HCl}$ nanosuspension intended for ophthalmic delivery. J Pharm Innov 2015;10:254-68.

22. El-Mahrouk GM, El-Gazayerly ON, Aboelwafa AA, Taha MS. Chitosan lactate wafer as a platform for the buccal delivery of tizanidine $\mathrm{HCl}$ : in vitro and in vivo performance. Int J Pharm 2014;467:100-12.

23. Shaji JE, Lal MA. Nanocarriers for targeting in inflammation. Asian J Pharm Clin Res 2013;6:3-12.

24. Fahmy UA. Nanoethosomal transdermal delivery of vardenafil for treatment of erectile dysfunction: optimization, characterization, and in vivo evaluation. Drug Des Dev Ther 2015;9:6129.

25. Lambert JD, Kim DH, Zheng R, Yang CS. Transdermal delivery of (-)-epigallocatechin-3-gallate, a green tea polyphenol, in mice. J Pharm Pharmacol 2006;58:599-604.

26. Ibrahim KE, Al-Mutary MG, Bakhiet AO, Khan HA. Histopathology of the liver, kidney, and spleen of mice exposed to gold nanoparticles. Molecules 2018;23:1848.

27. Benzie IF, Strain JJ. The ferric reducing ability of plasma (FRAP) as a measure of" antioxidant power": the FRAP assay. Anal Biochem 1996;15:1.

28. Pari L, Latha M. Protective role of scoparia dulcis plant extract on brain antioxidant status and lipid peroxidation in STZ diabetic male wistar rats. BMC Complementary Altern Med 2004;4:16.

29. Draper HH, Hadley M. Oxygen radicals in biological systems part b: oxygen radicals and antioxidants. Vol. 186. Meth Enzymol; 1990. p. 421-31.

30. Livak KJ, Schmittgen TD. Analysis of relative gene expression data using real-time quantitative PCR and the $2-\Delta \Delta C T$ method. Methods 2001;25:402-8.

31. Huo Q, Hao J, Shi R. Determination of catechin by highperformance liquid chromatography and ultraviolet spectrophotometer. Asian J Chem 2013;25:8940-2.

32. Dayan N, Touitou E. Carriers for skin delivery of trihexyphenidyl HCl: ethosomes vs. liposomes. Biomaterials 2000;21:1879-85.

33. Elsayed MM, Abdallah OY, Naggar VF, Khalafallah NM. Lipid vesicles for skin delivery of drugs: reviewing three decades of research. Int J Pharm 2007;332:1-6.

34. Paolino D, Lucania G, Mardente D, Alhaique F, Fresta M. Ethosomes for skin delivery of ammonium glycyrrhizinate: in vitro percutaneous permeation through human skin and in vivo anti-inflammatory activity on human volunteers. J Controlled Release 2005;106:99-110.

35. Agro AS, Garner ET, Wright III JW, de Escobar IC, Villeda B, Seidlin M. Clinical trial of ototopical ofloxacin for treatment of chronic suppurative otitis media. Clin Ther 1998;20:744-59.

36. Okonogi S, Oguchi T, Yonemochi E, Puttipipatkhachorn S, Yamamoto K. Improved dissolution of ofloxacin via solid dispersion. Int J Pharm 1997;156:175-80.

37. Mokhtar M, Sammour OA, Hammad MA, Megrab NA. Effect of some formulation parameters on flurbiprofen encapsulation and release rates of niosomes prepared from proniosomes. Int J Pharm 2008;361(1 Suppl 2):104-11.

38. Nounou M, El-Khordagui LK, Khalafallah NA, Khalil SA. In vitro drug release of hydrophilic and hydrophobic drug entities from liposomal dispersions and gels. Acta Pharmaceutica 2006;56:311-24.

39. Panwar P, Pandey B, Lakhera PC, Singh KP. Preparation, characterization, and in vitro release study of albendazoleencapsulated nanosize liposomes. Int J Nanomed 2010;5:101.
40. Tanwar H, Sachdeva R. Transdermal drug delivery system: a review. Int J Pharm Sci Res 2016;7:2274.

41. El Zaafarany GM, Awad GA, Holayel SM, Mortada ND. Role of edge activators and surface charge in developing ultra deformable vesicles with enhanced skin delivery. Int J Pharm 2010;397(1 Suppl 2):164-72.

42. Fang JY, Yu SY, Wu PC, Huang YB, Tsai YH. In vitro skin permeation of estradiol from various proniosome formulations. Int J Pharm 2001;215(1 Suppl 2):91-9.

43. Wu PS, Li YS, Kuo YC, Tsai SJ, Lin CC. Preparation and evaluation of novel transfersomes combined with the natural antioxidant resveratrol. Molecules 2019;24:600.

44. Forester SC, Lambert JD. The role of antioxidant versus pro-oxidant effects of green tea polyphenols in cancer prevention. Mol Nutr Food Res 2011;55:844-54.

45. Chacko SM, Thambi PT, Kuttan R, Nishigaki I. Beneficial effects of green tea: a literature review. Chinese Med 2010;5:1-9.

46. Li YM, Chan HY, Huang Y, Chen ZY. Green tea catechins upregulate superoxide dismutase and catalase in fruit flies. Mol Nutr Food Res 2007;51:546-54.

47. Nelson SK, Bose SK, Grunwald GK, Myhill P, McCord JM. The induction of human superoxide dismutase and catalase in vivo: a fundamentally new approach to antioxidant therapy. Free Radical Biol Med 2006;40:341-7.

48. Pal S, Dey SK, Saha C. Inhibition of catalase by tea catechins in free and cellular state: a biophysical approach. PLoS One 2014;9:e102460.

49. Britton C, Helmut S, Alberto B. Hydroperoxide metabolism in mammalian organ. Physiol Rev 1979;59:527-605.

50. Mohamadin AM, El-Beshbishy HA, El-Mahdy MA. Green tea extract attenuates cyclosporine a-induced oxidative stress in rats. Pharmacol Res 2005;51:51-7.

51. Awoniyi DO, Aboua YG, Marnewick J, Brooks N. The effects of rooibos (Aspalathus linearis), green tea (Camellia sinensis) and commercial rooibos and green tea supplements on epididymal sperm in oxidative stress-induced rats. Phytother Res 2012;26:1231-9.

52. Messarah M, Saoudi M, Boumendjel A, Kadeche L, Boulakoud MS, Feki AE. Green tea extract alleviates arsenic-induced biochemical toxicity and lipid peroxidation in rats. Toxicol Ind Health 2013;29:349-59.

53. Prabakar J, John T, Arumugham M, Kumar P. Go natural, say no to chemicals-a systematic review on effectiveness of green tea extract containing formulations on dental caries. Asian J Pharm Clin Res 2019;12:63-9.

54. Basu A, Sanchez K, Leyva MJ, Wu M, Betts NM, Aston CE, et al. Green tea supplementation affects body weight, lipids, and lipid peroxidation in obese subjects with metabolic syndrome. J Am Coll Nutr 2010;29:31-40.

55. Bornhoeft J, Castaneda D, Nemoseck T, Wang P, Henning SM, Hong MY. The protective effects of green tea polyphenols: lipid profile, inflammation, and antioxidant capacity in rats fed an atherogenic diet and dextran sodium sulfate. J Med Food 2012;15:726-32.

56. Cunha CA, Lira FS, Rosa Neto JC, Pimentel GD, Souza GI, da Silva $\mathrm{CM}$, et al. Green tea extract supplementation induces the lipolytic pathway, attenuates obesity, and reduces low-grade inflammation in mice fed a high-fat diet. Mediators Inflamm 2013. DOI:10.1155/2013/635470

57. Hassan AF, Kahtan M, Al-Shawi NN, Numan IT, Bahader GA. The cytoprotective activity of aqueous green tea extract against metronidazole and tinidazole genotoxic effect. Asian J Pharm Clin Res 2019;12:428-31.

58. Princen HM, van Duyvenvoorde W, Buytenhek R, Blonk C, Tijburg LB, Langius JA, et al. No effect of consumption of green and black tea on plasma lipid and antioxidant levels and on LDL oxidation in smokers. Arterioscler Thromb Vasc Biol 1998;18:833-41.

59. Erba D, Riso P, Bordoni A, Foti P, Biagi PL, Testolin G. Effectiveness of moderate green tea consumption on antioxidative status and plasma lipid profile in humans. J Nutr Biochem 2005;16:144-9.

60. Fukino Y, Ikeda A, Maruyama K, Aoki N, Okubo T, Iso H. Randomized controlled trial for an effect of green tea-extract 
powder supplementation on glucose abnormalities. Eur J Clin Nutr 2008;62:953-60.

61. Dulloo AG, Duret C, Rohrer D, Girardier L, Mensi N, Fathi MM, et al. Efficacy of a green tea extract rich in catechin polyphenols and caffeine in increasing 24-h energy expenditure and fat oxidation in humans. Am J Clin Nutr 1999;70:1040-5.

62. Dulloo AG, Seydoux J, Girardier L, Chantre P, Vandermander J. Green tea and thermogenesis: interactions between catechinpolyphenols, caffeine and sympathetic activity. Int J Obes $2000 ; 24: 252-8$.
63. Choo JJ. Green tea reduces body fat accretion caused by high-fat diet in rats through $\beta$-adrenoceptor activation of thermogenesis in brown adipose tissue. J Nutr Biochem 2003;14:671-6.

64. Lee MS, Kim CT, Kim Y. Green tea (-)-epigallocatechin-3-gallate reduces body weight with the regulation of multiple genes expression in adipose tissue of diet-induced obese mice. Ann Nutr Metab 2009;54:151-7.

65. Kim SJ, Bang CY, Guo YR, Choung SY. Anti-obesity effects of aster spathulifolius extract in high-fat diet-induced obese rats. J Med Food 2016;19:353-64 